Note

\section{Effect of Metal Salts and Fructose on the Autoxidation of Methyl Linoleate in Emulsions}

\author{
Ryo Yamauchi, Yukio Tatsumi, \\ Miyo Asano, Koji Kato \\ and Yoshimitsu UENO \\ Department of Agricultural Chemistry, \\ Gifu University, Gifu 501-11, Japan
}

Received September 7, 1987

Sugars such as pentose, hexose and reducing disaccharide have been demonstrated to be strong prooxidants of methyl linoleate or linoleic acid in aqueous emulsion systems. ${ }^{1 \sim 4)}$ In the previous papers, ${ }^{4,5}$, we have reported that the prooxidant effect of reducing sugars on the autoxidation of methyl linoleate depends on trace amounts of metal ions in the reaction system; these sugars reduce metal ions in the reaction system, and the reduced metal ions accelerate the peroxidation process. Such prooxidant effects of certain transition metal ions, primarily copper and iron, on edible oils is well known and is a constant cause of practical problems. ${ }^{6}$ ) This paper deals with the prooxidant effect of some transition metal ions on the autoxidation of methyl linoleate emulsions in the presence and absence of a reducing sugar, fructose. The peroxidation was carried out at two $\mathrm{pH}$ conditions, $\mathrm{pH} 7.0$ and 3.0. Especially, the pH 3.0 condition was a model of some acidic emulsifying foods such as salad dressings.

Autoxidation of methyl linoleate occurred under the following conditions: $10 \mathrm{~mm}$ methyl linoleate emulsion, $10 \mathrm{~mm}$ fructose and $10 \mu \mathrm{M}$ metal salt in $50 \mathrm{~mm}$ sodium phosphate buffer at $\mathrm{pH} 7.0$, or in $50 \mathrm{~mm}$ sodium acetate/ $\mathrm{HCl}$ buffer at $\mathrm{pH} 3.0$, containing $0.5 \%$ Triton $\mathrm{X}$ 100. The buffer solutions used in the experiments were treated with Dowex A-1 resin to remove the trace amounts of metal ions. ${ }^{7)}$ This autoxidation was carried out at $37^{\circ} \mathrm{C}$. The peroxide concentrations were directly determined in each $100 \mu$ of the sample by an iodometric method as previously described. ${ }^{5}$ For all experiments, the average values of triplicate runs are presented, which did not vary by more than $\pm 10 \%$.

Reducing sugars such as fructose have been reported to accelerate the autoxidation of methyl linoleate in the aqueous emulsion system. ${ }^{4,5}$ On the other hand, the addition of fructose did not accelerate the lipid peroxidation when endogenous metal ions in the reaction system were removed by treating with a chelating resin (Table I). The addition of metal salts alone showed little effect on the autoxidation of methyl linoleate, lipid per- oxidation being accelerated by the combined effect of a metal salt and fructose. $\mathrm{CuSO}_{4}$ plus fructose showed the most marked effect on the acceleration of lipid peroxidation. $\mathrm{FeSO}_{4}$ or $\mathrm{FeCl}_{3}$ plus fructose also proved to be a powerful prooxidant. The results substantiated our previous study ${ }^{5)}$ that the reducing sugar reduces a transition metal ion, and that this reduced metal ion accelerates the peroxidation. From this idea, $\mathrm{FeSO}_{4}$, a reduced form of the iron ion, should be a powerful prooxidant, but this sait did not accelerate the lipid peroxidation. This might have been due to spontanous oxidation of the ferrous ion at $\mathrm{pH}$ $7.0 .^{51}$ On the basis of our results, it seems likely that the reducing form of a metal ion, especially copper and iron ions, is one of the important elements controlling the lipid peroxidation reaction.

Table II shows the effect of metal salts and fructose on the autoxidation of methyl linoleate at $\mathrm{pH}$ 3.0. Lipid peroxidation was hardly accelerated by the combined effect of a metal salt and fructose. Reducing sugars could reduce the ferric ion to ferrous ion at the neutral $\mathrm{pH}$ condition ${ }^{55}$ On the other hand, fructose at $\mathrm{pH} 3.0$ hardly reduced the ferric ion (data are not shown here). Therefore, the combined effect of a metal salt and fructose did not appear at this condition. Among the various species of metal ion tested; $\mathrm{FeSO}_{4}$ was the most powerful prooxidant on the autoxidation of methyl linoleate, and $\mathrm{FeCl}_{3}$ also had a prooxidant effect at $\mathrm{pH} 3.0$, whereas these iron salts did not accelerate the peroxidation process at $\mathrm{pH}$ 7.0. According to O'Brien, ${ }^{87}$ the decomposition of linoleic acid hydroperoxide by transition metal salts was markedly $\mathrm{pH}$ dependent. $\mathrm{Fe}^{2+}$ and $\mathrm{Fe}^{3+}$ had a maximal activity at $\mathrm{pH}$ values below $5.5 . \mathrm{Cu}^{2+}$, on the other hand, had a maximal activity in the $\mathrm{pH}$ range of $5.5 \sim 6.0$. These results indicate that the prooxidant effect of metal salts on the lipid peroxidation was $\mathrm{pH}$ dependent.

Table I. Effect of Metal Salts on the Autoxidation of a Methyl Linoleate Emulsion AT PH 7.0 IN THE PRESENCE AND ABSENCE OF FRUCTOSE

\begin{tabular}{|c|c|c|c|c|}
\hline \multirow{3}{*}{ Metal salt } & \multicolumn{4}{|c|}{ Peroxide ( $\mathrm{mmol} / \mathrm{mol}$ of methyl linoleate) } \\
\hline & \multicolumn{2}{|c|}{ Without fructose } & \multicolumn{2}{|c|}{ With fructose } \\
\hline & $24 \mathrm{hr}$ & $48 \mathrm{hr}$ & $24 \mathrm{hr}$ & $48 \mathrm{hr}$ \\
\hline None & 0 & 3 & 0 & 6 \\
\hline $\mathrm{CdCl}_{2}$ & 0 & 9 & 97 & 168 \\
\hline $\mathrm{CoCl}_{2}$ & 0 & 3 & 62 & 126 \\
\hline $\mathrm{Cr}\left(\mathrm{NO}_{3}\right)_{3}$ & 8 & 20 & 99 & 213 \\
\hline $\mathrm{CuSO}_{4}$ & 3 & 46 & 568 & 803 \\
\hline $\mathrm{FeSO}_{4}$ & 3 & 12 & 310 & 514 \\
\hline $\mathrm{FeCl}_{3}$ & 4 & 8 & 230 & 555 \\
\hline $\mathrm{HgCl}_{2}$ & 2 & 13 & 14 & 41 \\
\hline $\mathrm{MnSO}_{4}$ & 2 & 14 & 20 & 63 \\
\hline $\mathrm{ZnSO}_{4}$ & 0 & 24 & 136 & 335 \\
\hline
\end{tabular}


Table II. EfFect of Metal Salts on the Autoxidation of a Methyl Linoleate Emulsion at pH 3.0 in the Presence AND ABSENCE OF FRUCTOSE

\begin{tabular}{|c|c|c|c|c|}
\hline \multirow{3}{*}{ Metal salt } & \multicolumn{4}{|c|}{ Peroxide ( $\mathrm{mmol} / \mathrm{mol}$ of methyl linoleate) } \\
\hline & \multicolumn{2}{|c|}{ Without fructose } & \multicolumn{2}{|c|}{ With fructose } \\
\hline & $24 \mathrm{hr}$ & $48 \mathrm{hr}$ & $24 \mathrm{hr}$ & $48 \mathrm{hr}$ \\
\hline None & 7 & 19 & 7 & 12 \\
\hline $\mathrm{CdCl}_{2}$ & 19 & 20 & 11 & 12 \\
\hline $\mathrm{CoCl}_{2}$ & 4 & 12 & 15 & 26 \\
\hline $\mathrm{Cr}\left(\mathrm{NO}_{3}\right)_{3}$ & 17 & 19 & 13 & 20 \\
\hline $\mathrm{CuSO}_{4}$ & 20 & 21 & 36 & 91 \\
\hline $\mathrm{FeSO}_{4}$ & 152 & 499 & 194 & 484 \\
\hline $\mathrm{FeCl}_{3}$ & 39 & 155 & 55 & 280 \\
\hline $\mathrm{HgCl}_{2}$ & 12 & 16 & 24 & 26 \\
\hline $\mathrm{MnSO}_{4}$ & 24 & 41 & 5 & 14 \\
\hline $\mathrm{ZnSO}_{4}$ & 19 & 23 & 14 & 23 \\
\hline
\end{tabular}

The iron salts was an important factor for the acceleration of methyl linoleate peroxidation at $\mathrm{pH} 3.0$. The free radical scavengers, butylated hydroxytoluene and $\alpha$ tocopherol, could inhibit the iron salt-catalyzed peroxidation, which implies the involvement of free radicals, possibly the peroxy and alkoxy radicals, in the peroxidation process. Such free radicals formed by the reaction of iron salts with lipid hydroperoxide cause the initiation of lipid peroxidation. ${ }^{9}$

There are a wide variety of emulsifying foods showing low $\mathrm{pH}$ values such as salad dressings. These products contain oil, water, acetic acid and many additives such as sugars, proteins and salts. Acetic acid has been reported to have a prooxidant effect on the autoxidation of methyl linoleate ${ }^{10)}$ In addition, the present study indicates that a trace amount of iron salts was an important factor on the oxidative deterioration of acidic oil products, and that a reducing sugar did not affect the acceleration of lipid peroxidation in the low $\mathrm{pH}$ condition.

\section{REFERENCES}

1) A. F. Mabrouk and L. R. Dugan, Jr, J. Am. Oil Chem. Soc., 38, 692 (1961).

2) A. F. Mabrouk, J, Am. Oil Chem. Soc., 41, 331 (1964).

3) N. Yamaguchi and A. Yamada, Nippon Shokuhin Kogyo Gakkaishi, 28, 303 (1981).

4) R. Yamauchi, Y. Aoki, T. Sugiura, K. Kato and Y. Ueno, Agric. Biol. Chem., 46, 2997 (1982).

5) R. Yamauchi, Y. Goto, K. Kato and Y. Ueno, Agric Biol. Chem., 48, 843 (1984).

6) S. E. O. Mahgoub and B. J. F. Hudson, Food Chem., 16, 97 (1985).

7) J. M. C. Gutteridge, Biochim. Biophys. Acta, 834, 144 (1985).

8) P. J. O'Brien, Can J. Biochem., 47, 485 (1969).

9) B. Halliwell and J. M. C. Gutteridge, Biochem. J., 219, 1 (1984).

10) K. Miyashita and T. Takagi, Agric. Biol. Chem., 51, 1179 (1987). 